\title{
Changes in health status of North Korean children and emerging health challenges of North Korean refugee children
}

Seong-Woo Choi, MD, PhD

Department of Preventive Medicine, Chosun University Medical School, Gwangju, Korea

The food shortage in North Korea is a serious situation that has spanned the mid-1990s to today. North Korean refugee children, even those born in North Korea, China, or South Korea, had poor nutritional status at birth; thus, their growth and nutritional status should be continuously monitored. This review focused on the health status of North Korean children and the nutritional status of North Korean refugee children upon settling in South Korea. Immediately after entering South Korea, North Korean refugee children were shorter and lighter than South Korean children and had a serious nutritional status. Over time, their nutrition status improved, but they remained shorter and lighter than South Korean children. A new obesity problem was also observed. Therefore, it is necessary to continuously monitor their growth and nutritional status.

Key words: Growth disorder, Nutritional status, Obesity, Democratic People's Republic of Korea, Refugees

\section{Key message}

- Among North Korean refugee (NKR) children under 5 years, $61 \%$ and $9.3 \%$ were underweight in 1998 and 2017, respectively.

- The immunization rate of NKR children exceeded $90 \%$ since 2006.

- For NKR children, protein-energy malnutrition was the \#1 cause of death in 2009 versus \#17 in 2019.

- In 2020, stunting affected $5.4 \%$ and $0.9 \%$ and obesity affected $10.7 \%$ and $2.7 \%$ of NKR versus South Korean children, respectively.

\section{Introduction}

In the mid-1990s, the nutritional status of the North Korean (NK) population was very serious due to food shortages. The United Nations (UN) reported that the prevalence of acute malnutrition was $32.7 \%$, while the prevalence of chronic malnutrition was as high as $74.1 \%$. ${ }^{1)}$ These food crises caused numerous NK people to escape from China or other neigh- boring countries. The total number of NK refugees (NKRs) entering South Korea (SK) reached 33,752 by the end of December 2020.2) Among them, 4,799 (14.2\%) were children and adolescents aged $0-19$ years. ${ }^{3)}$

In the early 2000s, when the number of NKRs increased rapidly, the mass media released articles about the retarded growth of NKR children, but only a few studies investigated their nutritional status. Moreover, most of the studies were one-off, and the timing and number of samples differed, so a comprehensive assessment of the growth and nutritional status of NKR children is lacking. Therefore, this study summarized the studies conducted to date and assessed how the growth and nutritional status of NKR children have changed.

\section{Health status of NK children}

\section{Child health}

International food aid has been provided since the United Nations Food Shortage Report on NK was published in mid19990s, and several surveys have assessed maternal and child health to verify the effectiveness of the food aid (Table 1$){ }^{4-}$ 10) The birth rates of low birth weight infants were $6.4 \%$ in 2000 and $6.7 \%$ in 2002 but gradually decreased to $3.1 \%$ in 2017. Among children under 6 months of age, the exclusively breastfed rate increased from $69.6 \%$ in 2002 to $88.6 \%$ in 2009 and then gradually decreased to $71.4 \%$ in 2017 . The vitamin A supplementation coverage rate in children aged 6-59 months was $80.2 \%$ in 2000 and gradually increased to $97.8 \%$ in 2012 . The percentage of children receiving oral rehydration solutions during an episode of diarrhea was $90.9 \%$ in 2000 versus $74.1 \%$ in 2017.

\section{Maternal health}

The proportion of more than 4 antenatal care visits was $95 \%$ in 2004 versus $93.7 \%$ in 2017 . The proportion of skilled birth attendants was $96.7 \%$ in 2000 versus $99.5 \%$ in 2017 . The proportion of childbirths that occurred at the health facility was 


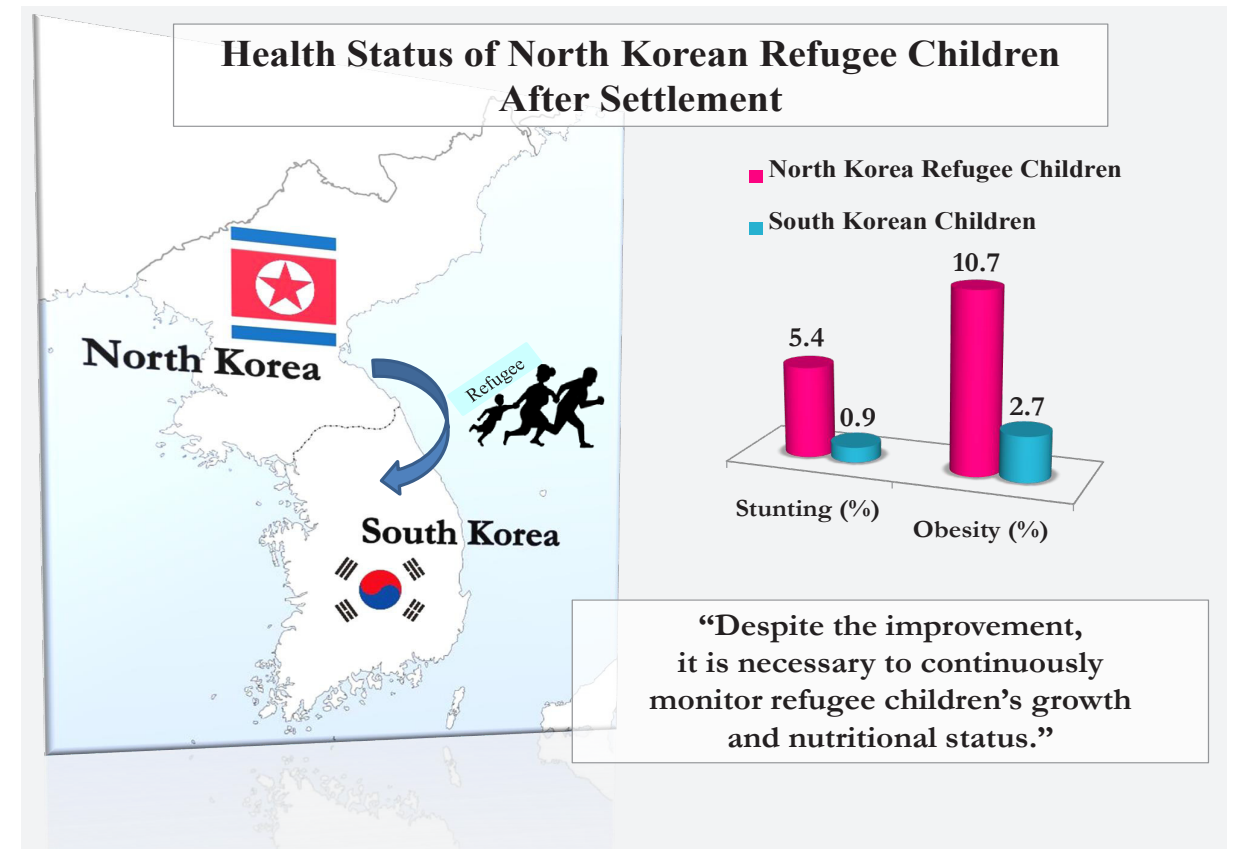

Graphical abstract

Table 1. Maternal and child health in North Korea

\begin{tabular}{|c|c|c|c|c|c|c|c|}
\hline Indicator & $1998^{\mathrm{a})}$ & $2000^{b)}$ & $2002^{c)}$ & $2004^{d)}$ & $2009^{e)}$ & $2012^{f)}$ & $2017^{9)}$ \\
\hline \multicolumn{8}{|l|}{ Child health } \\
\hline Birth rates of low birth weight & - & 6.4 & 6.7 & - & 5.7 & - & 3.1 \\
\hline Exclusively breastfed (<6 mo) & - & - & 69.6 & 65.1 & 88.6 & 68.9 & 71.4 \\
\hline Vitamin A supplementation coverage (6-59 mo) & - & 80.2 & 98.6 & 98.2 & 98.0 & 97.8 & - \\
\hline Receiving oral rehydration solutions during the episode of diarrhea & - & 90.9 & - & 69.8 & 74 & - & 74.1 \\
\hline Maternal health & & & & & & - & \\
\hline Antenatal care at least 4 times & - & - & - & 95.0 & 93.5 & - & 93.7 \\
\hline Skilled birth attendant & - & 96.7 & - & 97.1 & 100 & - & 99.5 \\
\hline Institutional deliveries & - & - & - & - & 94.7 & - & 92.2 \\
\hline \multicolumn{8}{|l|}{ Nutrition } \\
\hline Underweight $(<5 \mathrm{yr})$ & 60.6 & 27.9 & 20.2 & 23.4 & 18.8 & 15.2 & 9.3 \\
\hline Wasting $(<5 \mathrm{yr})$ & 15.6 & 10.4 & 8.1 & 7.0 & 5.2 & 4.0 & 2.5 \\
\hline Stunting $(<5 \mathrm{yr})$ & 62.3 & 45.2 & 39.2 & 37.0 & 32.4 & 27.9 & 19.1 \\
\hline
\end{tabular}

Values are presented as percent.

${ }^{a}$ Nutrition survey of the Democratic People's Republic of Korea 1998. ${ }^{\text {b) }}$ Report of the second multiple indicator cluster survey $2000 .{ }^{c}$ Report on the Democratic People's Republic of Korea nutrition assessment 2002. d) Democratic People's Republic of Korea 2004 nutrition assessment report of survey

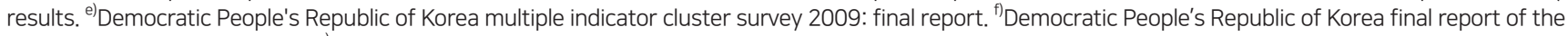
national nutrition survey 2012. ${ }^{9}$ Democratic People's Republic of Korea multiple indicator cluster survey 2017: survey findings report.

$94.7 \%$ in 2009 versus $92.2 \%$ in 2017.

\section{Nutrition}

Among children under the age of 5 years, the underweight rate was $60.6 \%$ in 1998 and then gradually decreased to $18.8 \%$ in 2009 and $9.3 \%$ in 2017. Similarly, the rates of wasting and stunting decreased from $15.6 \%$ and $62.3 \%$ in 1998 to $2.5 \%$ and $19.1 \%$ in 2017 , respectively.

\section{Immunization}

Fig. 1 shows the immunization rates of NK children from 1998 to 2019. ${ }^{11)}$ The Bacillus Calmette-Guérin vaccine immunization coverage rate was 69\% in 1998 versus $96 \%$ in 2002. It decreased to $88 \%$ in 2003 and then continued to fluctuate gradually, reaching 96\% in 2019. The DTP3 (third dose of diphtheria and tetanus toxoids and pertussis-containing vaccine) immunization coverage rate was as low as $43 \%$ in 1998 but has continued to increase since then, reaching 97\% in 2019. The Pol3 (third dose of polio vaccine) immunization coverage rate was $82 \%$ in 1998 , increased to $99 \%$ in 2002, and was $98 \%$ in 2019.

The MCV1 (first dose of measles-containing vaccine) immunization coverage rate was $49 \%$ in 1998 and increased rapidly to $98 \%$ in 2002 , and then gradually fluctuated, reaching $98 \%$ in 2019. The coverage rate of the HepB3 (three-dose hepatitis B vaccine) was very low at $27 \%$ in 2003 , increased sharply to $98 \%$ 


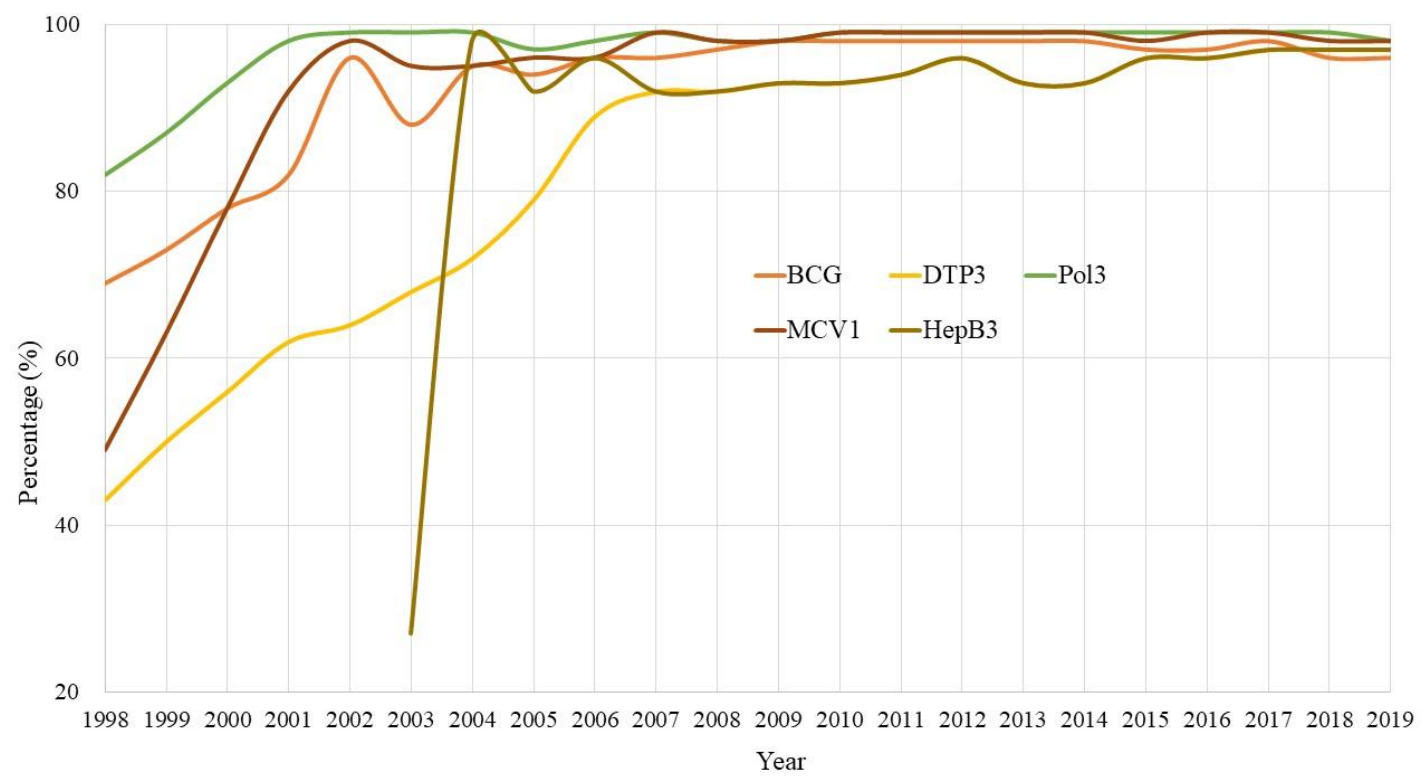

Fig. 1. Immunization coverage rate in North Korean children, 1998 and 2019. BCG, Bacillus Calmette-Gu rin vaccine; DTP3, three doses of diphtheria, tetanus toxoid, and pertussis; Pol3, three doses of oral polio vaccine; MCV1, first dose of measlescontaining vaccine; HepB3, three-dose hepatitis B vaccine.


Fig. 2. Top 10 causes of death in North Korean children in 2000 versus 2019. (A) 0-4 years. (B) 5-14 years. Orange circle: communicable, maternal, neonatal, and nutritional disease; blue circle: noncommunicable diseases; green circle: injuries.

in 2004 , and remained at $97 \%$ in 2019.

\section{Leading cause of death in NK children}

The changes in the leading cause of death in children with NK between 2000 and 2019 using data from the Institute for Health Metrics and Evaluation ${ }^{12)}$ are shown in Fig. 2. Among children under 5 years of age, protein-energy malnutrition was the most common cause of death in 2000 but sharply decreased in 2019, while the rates of measles and whooping cough decreased similarly in 2019. However, the rates of lower respiratory infections and diarrheal diseases were higher in 2019. In addition, the rates of injuries, such as drowning, foreign bodies, and road injuries, increased in 2019 compared to 2000.

In children aged 5-14 years, the most common cause of death in 2000 was protein-energy malnutrition, which decreased sharply in 2019, similar to what was noted in children under 5 years of age. The same infectious diseases, measles and meningitis, also declined in 2019, whereas lower respiratory infections maintained a similar ranking in 2019. The rates of injuries (drowning, road injury, interpersonal violence, and falls) and noncommunicable diseases (leukemia, congenital defects, brain cancer, and other malignant neoplasms) increased in 2019. 


\section{Health challenges of NKR children}

\section{Background of NKR children}

The backgrounds of NKR children can be divided into several categories $^{13)}$ : those who were born in NK but have moved to SK; those who were born in a third country such as China after one of their parents left NK and subsequently entered SK; and those who were born in SK after a parent settled in SK. The Ministry of Unification data includes only children born in NK. In fact, it is estimated that there are more NKR children living in South Korea than reported. These children are highly likely to have poor nutritional status at birth and have a low socioeconomic status (SES), even after settling in $\mathrm{SK}^{14)}$; therefore, their nutritional status must be regularly monitored.

\section{Growth status between NK and SK children}

After the NK famine of the mid-1990s, researchers have aimed to determine the growth and nutritional status of NK children using UN survey data (Table 2). In a study comparing the height and weight, NK children were 6-7 cm shorter and about $3 \mathrm{~kg}$ lighter than SK children. ${ }^{15)}$ In another study, NK children were up to $13 \mathrm{~cm}$ shorter and up to $7 \mathrm{~kg}$ lighter than SK children (Table 3). ${ }^{16)}$

\section{Growth and nutrition status after defecting from NK}

As the food shortage persisted and many NK citizens began escaping the country, investigators became concerned about the growth and nutritional status of NKR children (Table 4). NKRs generally stay in third countries (mainly China) for months to years before entering SK. One study assessed the growth status of NKR children residing in China. ${ }^{17)}$ The heights and weights of 436 NKRs aged 4-19 years old were measured, and their growth statuses were only $70 \%-90 \%$ of those of SK children.

\section{Growth and nutrition status immediately after SK entry}

Immediately after entering SK, NKRs undergo a medical examination at Hanawon. Some studies have evaluated the growth status of NKR children using Hanawon health data (Table 4). Of them, 30.2\% were shorter than the 3rd percentile of the SK standard, while 27.9\% weighed less than the 3rd percentile of the SK standard. ${ }^{18)}$ Similarly, another study using the Hanawon data of NKRs aged 6-20 years who entered SK in 1999-2007 reported that they were up to $16.3 \mathrm{~cm}$ shorter and up to $15.3 \mathrm{~kg}$ lighter than SK children. ${ }^{19)}$ Several other studies evaluated nutritional status using Hanawon health data. Among 283 NKRs younger than 18 years, the prevalence of stunting was $29.4 \%$, that of underweight was $10.4 \%$, and that of wasting

Table 2. Summary of studies on the nutritional status of North Korean children

\begin{tabular}{|c|c|c|c|c|c|c|c|c|c|c|}
\hline \multirow{3}{*}{ Study } & \multicolumn{4}{|c|}{ South Korean children } & \multicolumn{4}{|c|}{ North Korean children } & \multirow{3}{*}{ Findings } & \multirow{3}{*}{ Remark } \\
\hline & \multirow[b]{2}{*}{ Data } & \multirow[b]{2}{*}{ Year } & \multicolumn{2}{|c|}{ Subjects } & \multirow[b]{2}{*}{ Data } & \multirow[b]{2}{*}{ Year } & \multicolumn{2}{|r|}{ Subjects } & & \\
\hline & & & $\begin{array}{l}\text { Age } \\
\text { (yr) }\end{array}$ & $\begin{array}{c}\text { Number } \\
\text { (boys, girls) }\end{array}$ & & & $\begin{array}{l}\text { Age } \\
\text { (yr) }\end{array}$ & $\begin{array}{c}\text { Number } \\
\text { (boys, girls) }\end{array}$ & & \\
\hline $\begin{array}{l}\text { Central Bureau of Statistics, } \\
(2000)\end{array}$ & NA & NA & NA & NA & $\begin{array}{l}\text { Multiple indicator } \\
\text { cluster survey }\end{array}$ & 2000 & $<5$ & $\begin{array}{c}4,175 \\
(2,124,2,051)\end{array}$ & $\begin{array}{l}\text { Stunting, } 45.2 \% \text {; } \\
\text { underweight, } 27.9 \% \\
\text { wasting, } 10.4 \%\end{array}$ & NA \\
\hline $\begin{array}{l}\text { Central Bureau of Statistics, } \\
(2010)\end{array}$ & NA & NA & NA & NA & $\begin{array}{l}\text { Multiple indicator } \\
\text { cluster survey }\end{array}$ & 2009 & $<5$ & $\begin{array}{c}2,190 \\
(1,113,1,077)\end{array}$ & $\begin{array}{l}\text { Stunting, } 32.4 \% \text {; } \\
\text { underweight, } 18.8 \% \text {; } \\
\text { wasting, } 5.2 \%\end{array}$ & NA \\
\hline $\begin{array}{l}\text { Central Bureau of Statistics, } \\
\text { (2013) }\end{array}$ & NA & NA & NA & NA & $\begin{array}{l}\text { Multiple indicator } \\
\text { cluster survey }\end{array}$ & 2012 & $<5$ & $\begin{array}{c}8,036 \\
(4,115,3,921)\end{array}$ & $\begin{array}{l}\text { Stunting, } 27.9 \% \text {; } \\
\text { underweight, } 15.2 \% \text {; } \\
\text { wasting, } 4.0 \%\end{array}$ & NA \\
\hline $\begin{array}{l}\text { Central Bureau of Statistics, }{ }^{10)} \\
(2018)\end{array}$ & NA & NA & NA & NA & $\begin{array}{l}\text { Multiple indicator } \\
\text { cluster survey }\end{array}$ & 2017 & $<5$ & $\begin{array}{c}2,271 \\
(1,161,1,110)\end{array}$ & $\begin{array}{l}\text { Stunting, } 19.1 \% \text {; } \\
\text { underweight, 9.3\%; } \\
\text { wasting, } 2.5 \%\end{array}$ & NA \\
\hline
\end{tabular}

NA, Not Applicable

Table 3. Summary of studies on the growth status between North Korean and South Korean children

\begin{tabular}{|c|c|c|c|c|c|c|c|c|c|c|}
\hline \multirow{3}{*}{ Study } & \multicolumn{4}{|c|}{ South Korean children } & \multicolumn{4}{|c|}{ North Korean children } & \multirow{3}{*}{ Findings } & \multirow{3}{*}{ Remark } \\
\hline & \multirow[b]{2}{*}{ Data } & \multirow[b]{2}{*}{ Year } & \multicolumn{2}{|c|}{ Subjects } & \multirow[b]{2}{*}{ Data } & \multirow[b]{2}{*}{ Year } & \multicolumn{2}{|c|}{ Subjects } & & \\
\hline & & & $\begin{array}{l}\text { Age } \\
(y r)\end{array}$ & $\begin{array}{c}\text { Number } \\
\text { (boys, girls) }\end{array}$ & & & $\begin{array}{l}\text { Age } \\
(y r)\end{array}$ & $\begin{array}{l}\text { Number } \\
\text { (boys, girls) }\end{array}$ & & \\
\hline \multirow[t]{2}{*}{$\begin{array}{l}\text { Schwekendiek } \\
\text { and Park } \\
2009\end{array}$} & $\begin{array}{l}\text { Korean Research Institute } \\
\text { of Standards and Science }\end{array}$ & 1997 & NA & NA & UN survey & 1997 & $1.0-5.9$ & 3,770 & $\begin{array}{l}\text { North Korean children } \\
6-7 \mathrm{~cm} \text { shorter and } \\
\text { about } 3 \mathrm{~kg} \text { lighter }\end{array}$ & NA \\
\hline & $\begin{array}{l}\text { Korean Agency for Tech- } \\
\text { nology and Standards }\end{array}$ & 2004 & NA & NA & UN survey & 2002 & $1.0-5.9$ & 4,617 & $\begin{array}{l}\text { North Korean children } 8 \\
\text { cm shorter and about } 3 \\
\text { kg lighter }\end{array}$ & NA \\
\hline $\begin{array}{l}\text { Schwekendiek, } \\
2009\end{array}$ & $\begin{array}{l}\text { Korean Research Institute } \\
\text { of Standards and Science }\end{array}$ & 2004 & NA & NA & UN survey & 2002 & $<7$ & $\begin{array}{c}5,992 \\
(2,880,3,112)\end{array}$ & $\begin{array}{l}\text { North Korean children } \\
\text { upto } 13 \mathrm{~cm} \text { shorter and } \\
\text { upto } 7 \mathrm{~kg} \text { lighter }\end{array}$ & NA \\
\hline
\end{tabular}

NA, Not Applicable; UN, United Nations. 
Table 4. Summary of studies on the growth and nutrition status after defecting from North Korea

\begin{tabular}{|c|c|c|c|c|c|c|c|c|c|c|}
\hline \multirow[b]{3}{*}{ Study } & \multicolumn{4}{|c|}{ South Korean children } & \multicolumn{4}{|c|}{ North Korean refugee children } & \multirow{3}{*}{ Findings } & \multirow{3}{*}{ Remark } \\
\hline & \multirow[b]{2}{*}{ Data } & \multirow[b]{2}{*}{ Year } & \multicolumn{2}{|c|}{ Subjects } & \multirow[b]{2}{*}{ Data } & \multirow[b]{2}{*}{ Year } & \multicolumn{2}{|c|}{ Subjects } & & \\
\hline & & & $\begin{array}{l}\text { Age } \\
\text { (yr) }\end{array}$ & $\begin{array}{l}\text { Number } \\
\text { (boys, } \\
\text { girls) }\end{array}$ & & & $\begin{array}{l}\text { Age } \\
(y r)\end{array}$ & $\begin{array}{l}\text { Number } \\
\text { (boys, } \\
\text { girls) }\end{array}$ & & \\
\hline $\begin{array}{l}\text { Chang et al. }{ }^{17)} \\
2000\end{array}$ & $\begin{array}{l}\text { Physical growth refer- } \\
\text { ence value for child- } \\
\text { ren and youth of } \\
\text { South Korea }\end{array}$ & 1998 & NA & NA & $\begin{array}{c}\text { Self- } \\
\text { investigation }\end{array}$ & 1999 & 4-19 & $\begin{array}{c}436 \\
(306,130)\end{array}$ & $\begin{array}{l}\text { Height, weight of North Ko- } \\
\text { rean refugee children is } \\
70 \%-90 \% \text { of South Korean } \\
\text { children reference }\end{array}$ & $\begin{array}{l}\text { North Korean re- } \\
\text { fugee children in } \\
\text { China }\end{array}$ \\
\hline $\mathrm{Kim}^{18)} 2005$ & $\begin{array}{l}\text { Physical growth refe- } \\
\text { rence value for child- } \\
\text { ren and youth of } \\
\text { South Korea }\end{array}$ & 1998 & NA & NA & $\begin{array}{l}\text { Self- } \\
\text { investigation }\end{array}$ & 2005 & $9-19$ & $\begin{array}{c}43 \\
(18,25)\end{array}$ & $\begin{array}{l}\text { Stunting, } 30.2 \% \text {; under- } \\
\text { weight, } 27.9 \%\end{array}$ & $\begin{array}{l}\text { Immediately after } \\
\text { entering South } \\
\text { Korea }\end{array}$ \\
\hline Pak, $^{19)} 2010$ & $\begin{array}{l}\text { Korean Research Insti- } \\
\text { tute of Standards and } \\
\text { Science }\end{array}$ & 2004 & NA & NA & $\begin{array}{l}\text { Hanawon } \\
\text { data }\end{array}$ & $\begin{array}{l}1999- \\
2007\end{array}$ & $6-20$ & $\begin{array}{c}1,406 \\
(689,717)\end{array}$ & $\begin{array}{l}\text { North Korean refugee children } \\
\text { upto } 16.3 \mathrm{~cm} \text { shorter and } \\
\text { upto } 15.3 \mathrm{~kg} \text { lighter }\end{array}$ & $\begin{array}{l}\text { Immediately after } \\
\text { entering South } \\
\text { Korea }\end{array}$ \\
\hline $\mathrm{Pak}_{1}{ }^{20)} 2004$ & $\begin{array}{l}\text { Korean Research Insti- } \\
\text { tute of Standards and } \\
\text { Science }\end{array}$ & 1997 & NA & NA & $\begin{array}{l}\text { Hanawon } \\
\text { data }\end{array}$ & $\begin{array}{l}1999- \\
2003\end{array}$ & $0-20$ & $\begin{array}{c}283 \\
(152,131)\end{array}$ & $\begin{array}{l}\text { Stunting, } 29.4 \% \text {; under- } \\
\text { weight, 10.4\%; wasting: } 0 \%\end{array}$ & $\begin{array}{l}\text { Immediately after } \\
\text { entering South } \\
\text { Korea }\end{array}$ \\
\hline $\begin{array}{l}\text { Lee et al. }{ }^{21)} \\
2011\end{array}$ & $\begin{array}{l}\text { Korean National Growth } \\
\text { Charts }\end{array}$ & 2007 & NA & NA & $\begin{array}{c}\text { Self- } \\
\text { investigation }\end{array}$ & $\begin{array}{l}2009- \\
2010\end{array}$ & $7-14$ & $\begin{array}{c}109 \\
(44,65)\end{array}$ & $\begin{array}{l}\text { Stunting, } 18.6 \% \text {; under- } \\
\text { weight, } 14.7 \%\end{array}$ & $\begin{array}{l}\text { Immediately after } \\
\text { entering South } \\
\text { Korea }\end{array}$ \\
\hline
\end{tabular}

NA, Not Applicable

Table 5. Summary of studies on the nutritional status after settling in South Korea

\begin{tabular}{|c|c|c|c|c|c|c|c|c|c|c|}
\hline \multirow{3}{*}{ Study } & \multicolumn{4}{|c|}{ South Korean children } & \multicolumn{4}{|c|}{ North Korean refugee children } & \multirow{3}{*}{ Findings } & \multirow{3}{*}{ Remark } \\
\hline & \multirow[b]{2}{*}{ Data } & \multirow[b]{2}{*}{ Year } & \multicolumn{2}{|c|}{ Subjects } & \multirow[b]{2}{*}{ Data } & \multirow[b]{2}{*}{ Year } & \multicolumn{2}{|c|}{ Subjects } & & \\
\hline & & & $\begin{array}{l}\text { Age } \\
(y r)\end{array}$ & $\begin{array}{l}\text { Number } \\
\text { (boys, } \\
\text { girls) }\end{array}$ & & & $\begin{array}{l}\text { Age } \\
(\mathrm{yr})\end{array}$ & $\begin{array}{l}\text { Number } \\
\text { (boys, } \\
\text { girls) }\end{array}$ & & \\
\hline $\begin{array}{l}\text { Lee et al. }^{22)} \\
2015\end{array}$ & $\begin{array}{l}\text { Korea National Health } \\
\text { and Nutrition Exami- } \\
\text { nation Survey }\end{array}$ & $\begin{array}{l}2009- \\
2010\end{array}$ & $6-15$ & 202 & $\begin{array}{c}\text { Self- } \\
\text { investigation }\end{array}$ & NA & $6-15$ & $\begin{array}{c}70 \\
(35,35)\end{array}$ & $\begin{array}{l}\text { Changes between im- } \\
\text { mediately after entry } \\
\text { and settling about } 2 \mathrm{yr} \\
\text { Stunting: } 11.4 \% \rightarrow 5.7 \%, \\
\text { underweight: } 14.3 \% \rightarrow \\
1.4 \% \\
\text { Obesity: } 1.4 \% \rightarrow 5.7 \%\end{array}$ & $\begin{array}{l}\text { Settled in South } \\
\text { Korea about } 2 \\
\text { years } \\
\text { Age and sex } \\
\text { matched }\end{array}$ \\
\hline $\begin{array}{l}\text { Choi et al. } \\
2010\end{array}$ & $\begin{array}{l}\text { Korea National Health } \\
\text { and Nutrition Exami- } \\
\text { nation Survey }\end{array}$ & 2005 & $12-24$ & $\begin{array}{c}309 \\
(150,159)\end{array}$ & $\begin{array}{c}\text { Self- } \\
\text { investigation }\end{array}$ & $\begin{array}{l}2007- \\
2008\end{array}$ & $12-24$ & $\begin{array}{c}103 \\
(50,53)\end{array}$ & $\begin{array}{l}\text { North Korean refugee } \\
\text { children shorter and } \\
\text { lighter than SK }\end{array}$ & $\begin{array}{l}\text { Settled in South } \\
\text { Korea about } \\
2.4 \text { years } \\
\text { Age and sex } \\
\text { matched }\end{array}$ \\
\hline $\begin{array}{c}\text { Choi, }^{24)} \\
2020\end{array}$ & $\begin{array}{l}\text { Korean National Growth } \\
\text { Charts for children } \\
\text { and adolescents }\end{array}$ & 2017 & NA & NA & $\begin{array}{c}\text { Self- } \\
\text { investigation }\end{array}$ & $\begin{array}{l}2017- \\
2019\end{array}$ & $0-12$ & $\begin{array}{c}301 \\
(162,139)\end{array}$ & $\begin{array}{c}\text { Stunting, } 7.6 \% \text {; under- } \\
\text { weight, } 5.6 \% \text {; wasting, } \\
5.0 \% \text {; obesity, 5.0\% }\end{array}$ & $\begin{array}{l}\text { Settled in South } \\
\text { Korea about } \\
5.0 \text { years }\end{array}$ \\
\hline $\begin{array}{l}\text { Kim and } \text { Choi }^{25)} \\
2020\end{array}$ & $\begin{array}{l}\text { Korean National Growth } \\
\text { Charts for children and } \\
\text { adolescents }\end{array}$ & 2017 & NA & NA & $\begin{array}{l}\text { Self- } \\
\text { investigation }\end{array}$ & $\begin{array}{l}2017- \\
2019\end{array}$ & $0-18$ & $\begin{array}{c}526 \\
(276,250)\end{array}$ & $\begin{array}{l}\text { Stunting, } 7.0 \% \text {; under- } \\
\text { weight, } 6.8 \% \text {; wasting, } \\
\text { 5.3\%; obesity, } 9.1 \%\end{array}$ & $\begin{array}{l}\text { Settled in South } \\
\text { Korea about } \\
4.2 \text { years }\end{array}$ \\
\hline $\begin{array}{l}\text { Jeong et al. }{ }^{27)} \\
2020\end{array}$ & $\begin{array}{l}\text { Korea National Health } \\
\text { and Nutrition Exami- } \\
\text { nation Survey }\end{array}$ & $\begin{array}{l}2017- \\
2018\end{array}$ & $8-13$ & $\begin{array}{c}1,029 \\
(531,498)\end{array}$ & $\begin{array}{c}\text { Self- } \\
\text { investigation }\end{array}$ & $\begin{array}{l}2017- \\
2019\end{array}$ & $8-13$ & $\begin{array}{c}139 \\
(81,58)\end{array}$ & $\begin{array}{c}\text { Stunting, } 7.2 \% \text {; under- } \\
\text { weight, } 5.8 \% \text {; wasting, } \\
\text { 1.4\%; obesity, } 10.1 \%\end{array}$ & $\begin{array}{l}\text { Age and sex ma- } \\
\text { tched }\end{array}$ \\
\hline $\begin{array}{l}\text { Kim et al. } \\
2020\end{array}$ & $\begin{array}{l}\text { Korea National Health } \\
\text { and Nutrition Exami- } \\
\text { nation Survey }\end{array}$ & $\begin{array}{l}2017- \\
2018\end{array}$ & $0-7$ & $\begin{array}{c}224 \\
(120,104)\end{array}$ & $\begin{array}{l}\text { Self- } \\
\text { investigation }\end{array}$ & $\begin{array}{l}2017- \\
2019\end{array}$ & $0-7$ & $\begin{array}{c}112 \\
(60,52)\end{array}$ & $\begin{array}{c}\text { Stunting, } 5.4 \% \text {; under- } \\
\text { weight, } 4.59 \% \text {; wasting, } \\
\text { 7.1\%; obesity, } 10.7 \%\end{array}$ & $\begin{array}{l}\text { Age and sex ma- } \\
\text { tched }\end{array}$ \\
\hline
\end{tabular}

was $0 \% .^{20)}$ Another similar study reported that, among 109 NKRs aged 7-14 years, 18.6\% were stunted and 14.7\% were underweight. ${ }^{21)}$

\section{Nutritional status after settling in SK}

Once NKRs settled in SK, researchers investigated whether the nutritional status of the children had improved (Table 5). In one study, the researchers investigated 70 NKR children who had settled in SK. ${ }^{22)}$ They reported that the children's nutritional status improved from $11.4 \%$ to $5.7 \%$ for stunting and $14.3 \%$ to $1.4 \%$ for underweight by approximately 2 years after settling in SK. However, compared with sex- and age-matched SK individuals, NKR children were still significantly shorter and leaner than SK subjects. ${ }^{23)}$ In a study of 301 NKR children, the authors reported that the prevalence of stunting, underweight, and wasting was 7.6\%, 5.6\%, and 5.0\%, respectively. ${ }^{24)}$ Another 
study of 526 NKRs under 18 years who had lived in SK for approximately 4 years showed improved nutritional status, with the prevalence of stunting, underweight, and wasting of $7.0 \%$, $6.8 \%$, and $5.3 \%$, respectively. ${ }^{25)}$ The authors demonstrated that, despite this improvement, the nutritional status of NKR children remained serious, given that the subjects included children born in SK as well as children born in NK or third countries. In addition, comparison of the nutritional status of children born in the mid- to late 1990s and children born after 2000 revealed that the prevalence of stunting, underweight, and wasting among individuals born in the mid- to the late 1990s was higher than those born in NK after 2000. In the mid- to late 1990s, the food situation in North Korea was at its worst, and people born during this period are now entering adulthood, so their health status in adulthood should be carefully monitored. It is important to verify the thrifty phenotype hypothesis, which is the associations between poor nutrition in early life and the subsequent develop. ment of type 2 diabetes and the metabolic syndrome, by monitoring the incidence of chronic diseases in this population.

\section{Emerging obesity}

Shortly after NKRs enter SK, malnutrition remains a major health problem. ${ }^{21)}$ However, the prevalence of obesity increases in this population over time (Table 6). NKR children now face the "double burden" of both under- and overnutrition. ${ }^{25)}$ In a study using Hanawon data for NKRs, none of the children had a weight higher than the 97th percentile. ${ }^{21)}$ Moreover, using Hanawon data, another study reported that the prevalence of obesity was $1.4 \%$ at the time of SK entry but increased to 5.7\% after approximately 2 years. ${ }^{22}$ Approximately 4.2 years after NK children settled in SK, the prevalence of obesity had increased to $9.1 \%{ }^{25)}$

\section{Impact of SES}

The association between SES and the health and nutritional status of children is well known. ${ }^{26}$ ) Researchers recently evaluated whether this relationship is consistent with NKRs. In a study of 139 NKRs and 1,029 SK children aged 8-13, when SK children were classified into 4 SES groups (highest, moderatehigh, moderate-low, and lowest) according to monthly household income, the prevalence of stunting and underweight of NKR children was significantly higher than that of SK children with the lowest SES. ${ }^{27)}$ Similarly, in a study of 112 NKR and 224 sex- and age-matched SK preschool children, the prevalence of stunting and obesity in NKR children was significantly higher than that of SK children with a low SES. ${ }^{28)}$

\section{Future points to consider}

To date, various studies have aimed to determine the growth and nutritional status of NKR children, and several points are worth future consideration. First, it was a cross-sectional study with a small sample size. It is necessary to establish an NKR children cohort that includes a sufficient number to represent NKR children and periodically measure their growth and nutritional status to assess changes in nutritional status. Second, previous studies measured and reported nutrition and growth status on a one-off basis. However, there is a need for an intervention program to improve the nutritional status of NKR children. In particular, obesity rates increase rapidly over time after settling; therefore, nutrition education is urgently needed for NKR children and their parents and caregivers. Third, good maternal nutrition is the best kickstart for life. However, there is still no research on the health of NKR women. Therefore, it is necessary to develop intervention programs to improve the health and nutritional status of NKR women of childbearing age.

\section{Conclusions}

The nutritional status of children who defected due to the NK food shortage was very serious. The rates of severe malnutrition in these children improved over time after SK entry, but they remained short and light compared to SK children. In addition, the number of obese children began to increase over time.

\section{Footnotes}

Conflicts of interest: No potential conflict of interest relevant to this article was reported.

ORCID

Seong-Woo Choi @ https://orcid.org/0000-0002-6150-3934

Table 6. Comparisons of nutritional status between North Korean refugee children and South Korean children

\begin{tabular}{|c|c|c|c|c|c|c|c|c|c|c|c|c|}
\hline \multirow{3}{*}{$\begin{array}{l}\text { Nutritional } \\
\text { status }\end{array}$} & \multicolumn{9}{|c|}{ North Korean refugee children } & \multirow{2}{*}{\multicolumn{3}{|c|}{ South Korean children }} \\
\hline & \multicolumn{4}{|c|}{ Immediately after entering South Korea } & \multicolumn{5}{|c|}{ After settling in South Korea } & & & \\
\hline & $\begin{array}{l}\mathrm{Kim}_{1}^{18)} \\
2005\end{array}$ & $\begin{array}{l}\mathrm{Pak}^{20)} \\
2004\end{array}$ & $\begin{array}{l}\text { Lee } \\
\text { et al..11) } \\
2011\end{array}$ & $\begin{array}{l}\text { Lee } \\
\text { et al..' } \\
2015\end{array}$ & $\begin{array}{l}\text { Lee } \\
\text { et al., }{ }^{22)} \\
2015\end{array}$ & $\begin{array}{c}\text { Choi, }{ }^{24)} \\
2020\end{array}$ & $\begin{array}{c}\text { Kim and } \\
\text { Choi }^{25)} \\
2020\end{array}$ & $\begin{array}{l}\text { Jeong } \\
\text { et al. }{ }^{27)} \\
2020\end{array}$ & $\begin{array}{l}\text { Kim } \\
\text { et al. }{ }^{28)} \\
2020\end{array}$ & $\begin{array}{l}\text { Lee } \\
\text { et al., }{ }^{22)} \\
2015\end{array}$ & $\begin{array}{l}\text { Jeong } \\
\left.\text { et al. }{ }^{27}\right) \\
2020\end{array}$ & $\begin{array}{l}\text { Kim } \\
\text { et al. }^{28)} \\
2020\end{array}$ \\
\hline Stunting & 30.2 & 29.4 & 18.6 & 11.4 & 5.7 & 7.6 & 7.0 & 7.2 & 5.4 & 1.0 & 1.6 & 0.9 \\
\hline Underweight & 27.9 & 10.4 & 14.7 & 14.3 & 1.4 & 5.6 & 6.8 & 5.8 & 4.5 & 6.4 & 2.4 & 3.6 \\
\hline Wasting & - & 0 & - & - & & 5.0 & 5.3 & 1.4 & 7.1 & - & 1.4 & 6.7 \\
\hline Obesity & - & - & - & 1.4 & 5.7 & 5.0 & 9.1 & 10.1 & 10.7 & 6.4 & 10.1 & 2.7 \\
\hline
\end{tabular}




\section{References}

1. Katona-Apte J, Mokdad A. Malnutrition of children in the Democratic People's Republic of North Korea. J Nutr 1998;128:1315-9.

2. Ministry of Unification. Entry status of North Korean refugees 2020 [Internet]. Seoul (Korea): Ministry of Unification; [cited 2021 Mar 31]. Available from: https://www.unikorea.go.kr/unikorea/business/statistics.

3. Ministry of Unification. Entry status of North Korean refugees by age 2020 [Internet]. Seoul (Korea): Ministry of Unification; [cited 2021 Mar 31]. Available from: https://www.unikorea.go.kr/unikorea/business/ statistics.

4. Central Bureau of Statistics. Nutrition Survey of The Democratic People's Republic of Korea Pyongyang (DPRK): Central Bureau of Statistics, 1998.

5. Central Bureau of Statistics. Report of the second multiple indicator cluster survey 2000, DPRK. Pyongyang (DPRK): Central Bureau of Statistics, 2000.

6. UNICEF, WFP, Central Bureau of Statistics. Report on the DPRK Nutrition Assessment 2002. Pyongyang (DPRK): Central Bureau of Statistics, 2003.

7. Central Bureau of Statistics. DPRK 2004 Nutrition Assessment Report of Survey Results. Pyongyang (DPRK): Central Bureau of Statistics, 2005.

8. UNICEF, Central Bureau of Statistics. DPRK Multiple indicator cluster survey 2009: final report. Pyongyang (DPRK): Central Bureau of Statistics, 2010.

9. UNICEF, WFP, WHO, Central Bureau of Statistics. Democratic People's Republic of Korea Final report of the National Nutrition Survey 2012. Pyongyang (DPRK): Central Bureau of Statistics, 2013.

10. UNICEF, Central Bureau of Statistics. DPR Korea Multiple indicator cluster survey 2017: survey findings report. Pyongyang (DPRK): Central Bureau of Statistics and UNICEF, 2018.

11. WHO vaccine-preventable diseases: monitoring system. 2020 global summary [Internet]. Geneva (Switzerland): World Health Organization; 2020 [cited 2021 Apr 5]. Available from: https://apps.who.int/immunization_monitoring/globalsummary.

12. The Institute for Health Metrics and Evaluation. Global Burden of Disease Study 2019 results by location, cause, and risk factor [Internet]. Seattle (WA): The Institute for Health Metrics and Evaluation; 2019 [cited 2021 Mar 31]. Available from: https://vizhub.healthdata.org/gbdc ompare/.

13. Lee KY, Kim MK. Diversity of youths with a background of defection from North Korea: assistance policy analysis and implications. J Northeast Asia Res 2015;30:93-129.

14. Korea Hana Foundation. Settlement survey of North Korean refugees in South Korea. Seoul (Korea): Ministry of Unification, 2019.
15. Schwekendiek D, Pak S. Recent growth of children in the two Koreas: a meta-analysis. Econ Hum Biol 2009;7:109-12.

16. Schwekendiek D. Height and weight differences between North and South Korea. J Biosoc Sci 2009;41:51.

17. Chang N, Kang EY, Lee JM, Lee MK. Anthropometric measurements and dietary patterns of North Korean migrant children in China. Korean J Nutr 2000;33:324-31.

18. Kim YY. An evaluation of the health status of children from North Korea. Health Nurs 2005;17:55-63.

19. Pak S. The growth status of North Korean refugee children and adolescents from 6 to 19 years of age. Econ Hum Biol 2010;8:385-95.

20. Pak S. The biological standard of living in the two Koreas. Econ Hum Biol 2004;2:511-21.

21. Lee IS, Park HR, Kim YS, Park HJ. Physical and psychological health status of North Korean defector children. Child Health Nurs Res 2011;17:25663.

22. Lee SK, Nam SY, Hoffman D. Changes in nutritional status among displaced North Korean children living in South Korea. Ann Hum Biol 2015;42:581-4.

23. Choi SK, Park SM, Joung H. Still life with less: North Korean young adult defectors in South Korea show continued poor nutrition and physique. Nutr Res Pract 2010;4:136-41.

24. Choi SW. Growth and nutritional status of children in North Korean refugee families. J Korean Soc Matern Child Health 2020;24:96-101.

25. Kim SY, Choi SW. Double burden of malnutrition and obesity in children and adolescents from North Korean refugee families. PLoS One 2020; 15:e0241963.

26. Currie J, Stabile M. Socioeconomic status and child health: why is the relationship stronger for older children? Am Econ Rev 2003;93:1813-23.

27. Jeong YJ, Choi SW, Kim SY. The comparison of growth state and nutritional disorder between children from families of North Korean refugees and South Korea: with the children aged from 8 to 13. HSS21 2020;11:2165-75.

28. Kim SY, Park SY, Choi SW. Comparison of malnutrition status in preschool children between North Korean refugee families and South Korean families. J Health Info Stat 2020;45:255-60.

How to cite this article: Choi SW. Changes in health status of North Korean children and emerging health challenges of North Korean refugee children Clin Exp Pediatr 2021;64:5528. https://doi.org/10.3345/cep.2021.00192 